\title{
Do events contribute to the brand of Novi Sad? A millennials` perspective
}

\author{
Đurđica Jojić Novaković ${ }^{1 *}$, Marija Mandarić \\ ${ }^{1} \mathrm{PhD}$ student, University of Kragujevac, Faculty of Hotel Management and Tourism in \\ Vrnjačka Banja, Serbia \\ ${ }^{2}$ University of Kragujevac, Faculty of Hotel Management and Tourism in Vrnjačka Banja, \\ Serbia
}

\begin{abstract}
In the era of the global economy and more expressed need for obtaining a competitive advantage, strong brands and the branding process itself gain importance, which is why brand management principles are being applied even to geographical areas and destinations. Events and festivals represent an important element of brand destination, i.e. of cities worldwide, whereas in strategic documents related to the tourism both of the Republic of Serbia and of the city of Novi Sad, they are recognised as priority tourist products. The topic of this research is the analysis of importance of festivals for the "city of festivals" i.e. Novi Sad, but from the point of view of population that had little attention of researchers millennials. Millennials, i.e. those born in the 1990's, are the largest generation humankind ever had and their attitudes are dominating on the market. The research conducted in May 2018 on a sample of 102 students in Novi Sad has shown absolute domination of Exit festival in all aspects, but also some other interesting characteristics of Novi Sad brand.
\end{abstract}

Keywords: Novi Sad, millennials, festivals, branding, destination

JEL classification: M31, Z32

\section{Doprinos manifestacija brendiranju Novog Sada: istraživanje stavova milenijalaca}

Sažetak: U doba globalne ekonomije i sve izraženije potrebe za sticanjem konkurentske prednosti, jaki brendovi i proces brendiranja dobijaju sve više na značaju, zbog čega se principi brend menadžmenta sve češće primenjuju i na geografska područja i destinacije. Manifestacije i festivali predstavljaju značajan element brenda destinacija, odnosno gradova svugde u svetu, a i u strateškim dokumentima vezanim za turizam i Republike Srbije i grada Novog Sada, prepoznati su kao prioritetni turistički proizvodi. Istraživanje se bavi analizom značaja festivala za „grad festivala“, odnosno Novi Sad, ali sa aspekta do sada malo istraživane populacije - milenijalaca. Milenijalci, tj. oni rođeni u 1990-im godinama, su najbrojnija generacija koju je čovečanstvo do sada imalo i njihovi stavovi polako počinju da preovladavaju na tržištu. Istraživanje koje je sprovedeno u maju 2018. na uzorku od 102 studenta u Novom Sadu pokazalo je apsolutnu dominaciju Exit festivala u svim aspektima, ali i druge interesantne odrednice brenda Novog Sada.

Ključne reči: Novi Sad, milenijalci, festivali, brendiranje, destinacija JEL klasifikacija: M31, Z32

*djurdjica.jojic@gmail.com 


\section{Introduction}

The city of Novi Sad has been pronounced the Europan Capital of Culture 2021. It is the first time, since 1985 when this project started, that a city from the Balkans i.e. from exYugoslavia has been designated as a capital (and only $4^{\text {th }}$ time for the city outside Europan Union).

This project started in 1985 when ministers of culture of Greece, Melina Mercouri, and of France, Jack Lang, came up with an idea to establish institution of European capital of culture, which would be announced each year, with the intention to connect people of Europe and to increase awareness of common history and values. Quicikly it became one of the most important events in Europe, and the chosen cities have each year become role models of richness and diversified cultural heritage of Europe (Novi Sad 2021, 2018).

The project of European culture capital is designed in such a way to emphasize richness and diversification of cultures in Europe, to celebrate common characteristics of culture that Europeans share, to increase the sense of belonging to the same cultural area of citizens of Europe and to encourage contribution of culture to the development of cities. Besides that, the experience showed that this event is an excellent opportunity to improve the international profile of those cities, to improve the image of the city in the eyes of their own residents, to revive cultural life and finally to boost tourism (European Commission, 2018).

Process of the application and selection criteria are complex and have several phases, whereas criteria for the selection are the following (European Commission, 2014):

1. Contribution to the long term culture strategy;

2. Cultural and artistic content;

3. European dimension;

4. Reach i.e. involvement of local population;

5. Management (with special attention to city brand management);

6. Capacity for realisation.

From the above mentioned it is obvious that quite a lot of attention is given to residents, and to the importance of their integration in the destination itself and in all (tourism) activites that take place at the destination. Involvement of the local community is crucial to obtain long term sustainability of image of the destination (Ryan \& Montgomery, 1994; Ooi \& Strandgaard Pedersen, 2010; Nunkoo \& Gursoy, 2012). Not only tourists, but residents as well expect from cities and destinations to offer rich content, and among all events and manifestations that can cover all types of interest and themes, from fun to business and lifestle events (Getz, 2016). Further, debating on sustainability of events, (Henderson, 2011) argues that involvement of residents is one of the three main pillars which need to be in balance so that some event can achieve long term sustainability, with other two being caring for the environment (ecological pillar) and profit (financial pillar).

Therefore, the issue of branding of the city arises, as support of residents is a very important factor for successful and sustainable functioning of a destination from a tourist point of view. As branding of a destination is a very similar concept to the concept of branding with the corporate brand as the main one, participants of the organisation or in this case inhabitants of the city, must give their full support and truly believe in brand, which is one of the five main principles of such branding strategy (Veljković, 2010). A strong city brand can provide lots of benefits for its residents and especially to the younger population, in sense to feel proud to live in a city with the strong brand, to believe and support city public policy, hence the tourist activities that take place in that city. According to Morgan et al. (2015), the most effective strategy for a destination to manage its image is based upon its own population, 
companies and organisations. If all of them combined send a unique, convincing and interesting message to the world, then we can argue that the destination has control over its image. However, little research was devoted to the part of population referred to as "millennials", i.e. its young population. The aim of this research is to explore millennials' perspective on whether, and how, events contribute to the image of Novi Sad, as numerous events tend to be one of the most distinguished characteristics of Novi Sad's image (Grad Novi Sad, 2018).

\section{The branding of a tourist destination}

Globalisation is one of the main characteristics of the modern world economy. It is a process of connecting to the world. In other words, it implies elimination of economic borders, fast overcoming of geographical distances, connecting of business partners, consumers and information flows, i.e. growth of international trade and transnational interactions. In order to achieve the success of the global market, a company should have a strategic approach in brand creation, in order to win the fight of large corporations with the goal of satisfying demands of buyers all over the world. Along with the globalisation of the world's economy, the importance of the concept of competitiveness becomes dominant both in theory and practice. Traditional sources of competitiveness were based on economy of scale, while modern ones are based on intangible investment i.e. intangible assets, one of the most important elements being technological know-how. However, even product's superiority isn't guarantee for success anymore. It is a brand that is intangible assets which is hard to copy. Therefore it is the brand that has got a critical role in achieving and maintaining a competitive advantage (Mandarić, 2016).

The American Marketing Association defines a brand as a "name, term, sign, symbol, or design, or combination of them intended to identify the goods and services of one seller or group of sellers and to differentiate them from those of competition" (Kotler \& Gertner, 2002). But a brand is the term that means not only some specific product or service, but also its transferred characteristics such as some special values, beliefs and feelings, and image it carries. In the early stage of mass production, branding was the process of marking or "labelling" of animals, i.e. cattle, so that people know whose farm they belong to. Later on the meaning of a brand expanded and developed and today it means "the way in which a consumer sees, senses and understands certain marked product or service in all its dimensions" (Veljković, 2010).

In the modern world, where today there are over seven billion people, creating a brand destination is a challenge to national or macro-economic aspect. In the Republic of Serbia, the present problems such as the low standard of living, unemployment and underdeveloped infrastructure, are essential characteristics of both urban and rural areas. The need to attract tourists, to find new tourist attractions and to offer a unique positive experience, requires that all makers of tourist offer consciously approach the process of branding. Success in attracting tourists is determined by the strategic approach to branding. Branding encourages the positive association to a specific geographic location and creates a positive image of the destination in order to attract more visitors. Geographical territories and rural areas as carriers of the brand can have a huge impact on the development of tourism and economic activity of a region or country. Territorial or place marketing is studied as a special discipline in the developed countries, where each region is approached with special care, both in the economic and tourist sense. It is not possible to change the name of territory and sites, but it is possible to customize the branding strategy, so that it promotes local values in the awareness of the general public. Traditional products and services from a specific destination 
should be improved by slogans, symbols, legends, with the aim of better promoting the region both at domestic and foreign markets (Mandarić et al., 2017).

Place branding is defined as "the practice of applying brand strategy and other marketing techniques and disciplines to the economic, political and cultural development of cities, regions and countries" (Ashworth \& Kavaratzis, 2009). The implementation of marketing philosophy and methodology, or at least of marketing techniques that were easy to adapt and use in the practice of city governance, has been mirrored by the increasing interest of academics from various fields, who believe that the principles of marketing are, with the necessary modifications, applicable to cities and their operational environment (Kavaratzis, 2004). The practice of branding places as destinations - places to visit - is now a wellestablished aspect of public administration, local authorities were encouraged to become more strategic, developing and implementing public policy in collaboration with key stakeholder and interest groups (Hankinson, 2009; Paddison \& Biggins, 2017). Tourist destinations, i.e. geographical areas, whether they are cities, regions or countries, are facing increasing competition, and fight for tourists as well as for resources. Globalisation era enables an easier flow of people, goods and of capital which can be development chance for some destinations, or break and loss for others. Just like some classic product, a destination can be subject of branding, too. A destination brand is a name, symbol, logo and other visual elements which serve to identify and separate destination from its competition. It offers a promise of unforgettable experience by travelling to a certain destination, to potential visitors, and to those who have already visited it, it serves to remind them and strengthen their nice memories (Mandarić \& Milićević, 2016).

Goals of destination branding are: attracting visitors, both tourists and business people; attracting new businesses, i.e. business operations from other areas, as well as keeping and expansion of existing ones; export and investments increase; increased population or change of its structure (Veljković, 2010).

It is clear that a destination brand should have all the elements that a product or service brand has got. In the context of a destination, one of the important brand aspects are certainly events and manifestations which take place, as an element of offer and as an element of city's competitive advantage and of its identity (Yuan \& Chong, 2006; Lee \& Arcodia, 2011; Riza, 2015; Anastassova \& Luizov, 2016).

\section{Influence of events on a destination}

There are numbers of examples in literature which emphasize the importance of events from many aspects and especially from the aspect of tourism and the general development of a destination where the event takes place. Positive experience from some event transfers to the positive attitude about the region or destination where this event took place (Yuan \& Jang, 2008; Mason \& Paggiaro, 2012; Folorunso Adeyinka-Ojo \& Khoo-Lattimore, 2013) therefore manifestations can be considered as a leverage i.e. as a tool for destination promotion. Besides this, manifestations cause a number of other effects on a destination: they attract visitors and therefore foster business activity and increase employment, they make a destination more popular, but there are also negative ones such as a negative impact on the environment and/or local community (Anastassova \& Luizov, 2016).

Carnival in Rio de Janeiro, Mardi Gras in New Orleans, Glastonbury festival in England, San Remo festival in Italy, New Year's concert in Vienna are only the examples of manifestations that are popular worldwide. Besides permanent manifestations, there are also manifestations that each time change its venue, such as the Olympic games, the Eurovision 
Song Contest, World Championship in football, Expo etc. These manifestations also can contribute a lot in the popularisation of a destination (Arnegger \& Herz, 2016).

In accordance with extensive research and analysis conducted by authors of the Strategy of Development of Tourism of the Republic of Serbia 2016-2025, key tourist products are defined, the two most important being the tourism of cities and that of manifestations i.e. events (Vlada Republike Srbije, 2016). Similarly, the City of Novi Sad adopted the Programme of the development of tourism of Novi Sad 2018-2022 in which also the two most important products are business events, cultural events and events in general ( $\mathrm{Grad}$ Novi Sad, 2018).

\section{The importance of youth population}

There are a few generations identified in the literature. Although the boundaries cannot be precisely set, generations of people born in the period from the late 1980's to the late 1990's are named millennials, i.e. generation $\mathrm{Y}$. The generation to follow is generation $\mathrm{Z}$, referring to those born in the period after. This is the largest generation that human mankind has ever had. Today they form $1 / 3$ of the world's population (Fromm, 2011). This generation has specific characteristics, which cause big changes in all aspects of society and economy, therefore in tourism, too. One of the most important trends in modern tourism, which this generation has contributed to, is a change in the motives of travel, where tourists are less interested in a classic sun-sand-sea concept and seek more excitement, new experiences and adventures. This generation grew up with modern technologies so partially thanks to them it is that importance of digital technologies and modern means of communication became critical for all actors in tourist offer. They have such a different set of needs, habits, behaviour, thinking process and system of values, that creators and promoters of tourist offer already now have to form special segments for milleanials only, should they wish to be successful. Some of the main characteristics of this population are the following: they easily understand digital technologies and are always "connected"; they have short span of attention; they are very well informed; they are susceptible to influence of trend and role models; they are not materialists and instead of purchasing a house or a car they rather spend money on travelling; they are extremely price sensitive; they are considered to be disloyal consumers and have very unpredictive purchasing habits.

Millennials already represent the strongest group when it comes to the consumers' power and it is only the matter of time when the will dominate so much that their needs, motives and habits will overtake the whole market (Starčević \& Konjikušić, 2018).

In accordance with all above mentioned statements, the research has been designed to have millennials as the target population (i.e. students of the city of Novi Sad). The goal of the research was to examine the attitude of millennials about the contribution of manifestations to the branding and positioning of Novi Sad as a famous cultural destination.

\section{The influence of manifestations to the branding of Novi Sad}

Collection of primary data in the research has been realised using a method of enquiry. A questionnaire has been created based on questionnaires in similar researches which examine these topics (Richards \& Wilson, 2004; Anastassova \& Luizov, 2016; Grad Novi Sad, 2018) and it consists of the two parts. The first part contains 12 questions related to the opinion of respondents on manifestations that take place in Novi Sad and their influence on image and brand of the city. Out of these, 5 questions are open-ended and 7 questions are closed-ended. The other part of the questionnaire is related to the demographic characteristics of respondents. 
The enquiry has been conducted using the technique of personal interview of students within the Campus of the University of Novi Sad (54 respondents) and partially using e-mail survey, via internet i.e. by filling in the survey online (48 respondents), in May 2018. Out of a total of 110 inquiries distributed, 102 returned fulfilled, which makes a rate of respondents satisfactory, $92.7 \%$.

The data analysis was done using Microsoft Excel as well as a statistical package for data analysis IBM SPSS 20.0.

\subsection{The results of the empirical research}

The total number of 102 answers has been analysed in this research. The majority of the sample consisted of female persons, $70.6 \%$ compared to $29.4 \%$ of male respondents, and the majority in terms of age belongs to persons from 19 to 22 years (Table 1).

Table 1: Demographic characteristics of the sample

\begin{tabular}{|c|c|c|c|c|c|c|c|c|c|c|c|c|c|c|c|}
\hline Variable & \multicolumn{2}{|c|}{ Gender } & \multicolumn{10}{|c|}{ Age } & \multicolumn{3}{|c|}{$\begin{array}{c}\text { Place of living } \\
\text { before studying }\end{array}$} \\
\hline Category & Male & Female & 2 & ஜి & $\vec{\sim}$ & ปี & $\ddot{\imath}$ & $\stackrel{\sim}{\sim}$ & 2 & ㄴ. & $\hat{\imath}$ & $\stackrel{\infty}{\sim}$ & $\begin{array}{l}\text { Novi } \\
\text { Sad }\end{array}$ & $\begin{array}{l}\text { Outside } \\
\text { Novi Sad, } \\
\text { rural area }\end{array}$ & $\begin{array}{c}\text { Outside } \\
\text { Novi Sad, } \\
\text { urban area }\end{array}$ \\
\hline $\begin{array}{c}\text { Frequency } \\
(\%)\end{array}$ & 70.6 & 29.4 & $\hat{m}$ & $\stackrel{0}{9}$ & $\ddot{n}$ & $\begin{array}{l}0 \\
\infty \\
\infty\end{array}$ & $\begin{array}{l}\infty \\
\infty \\
\infty\end{array}$ & $\begin{array}{l}\infty \\
\infty \\
\infty\end{array}$ & $\begin{array}{l}\hat{n} \\
\text { in }\end{array}$ & $\stackrel{\leftrightarrow}{\sim}$ & $\stackrel{\circ}{\mathrm{i}}$ & $\stackrel{\vartheta}{n}$ & 38.2 & 37.3 & 24.5 \\
\hline
\end{tabular}

Source: Author's own research

When asked what their first association is when they think of Novi Sad, the majority of respondents chose "architecture and ambience" (36.3\%). The next two most common associations are "Danube, quay, Strand" (19.6\%) and "Exit and other festivals" (18.6\%). Other marks have less than $10 \%$ (table 2). These results correspond to the research conducted for writing of the Programme for development of tourism of Novi Sad, in which respondents most frequently stated that their first association for Novi Sad were Exit festival, food, Danube, people, Fortress etc. (Grad Novi Sad, 2018).

Table 2: Respondents' first association of Novi Sad

\begin{tabular}{|r|l|c|}
\hline No. & Mark of Novi Sad & $\begin{array}{c}\text { Frequency } \\
(\%)\end{array}$ \\
\hline 1 & $\begin{array}{l}\text { Architecture and ambience - } \\
\text { Petrovaradin fortress, cathedral, } \\
\text { Miletic square, Danube park etc. }\end{array}$ & 36.3 \\
\hline 2 & Danube, quay, Strand & 19.6 \\
\hline 3 & Exit and other festivals & 18.6 \\
\hline 4 & Multicultural Vojvodina & 7.8 \\
\hline 5 & Food and drink & 4.9 \\
\hline
\end{tabular}

\begin{tabular}{|l|l|c|}
\hline No. & Mark of Novi Sad & $\begin{array}{c}\text { Frequency } \\
(\%)\end{array}$ \\
\hline 6 & $\begin{array}{l}\text { Culture, local } \\
\text {,tambura“ musicians, } \\
\text { Djordje Balasevic }\end{array}$ & 4.9 \\
\hline 7 & Bicyclists & 3.9 \\
\hline 8 & $\begin{array}{l}\text { People and their } \\
\text { kindness }\end{array}$ & 2.9 \\
\hline 9 & IT industry & 1.0 \\
\hline 10 & $\begin{array}{l}\text { Something else } \\
\text { (specify what) }\end{array}$ & 0.0 \\
\hline
\end{tabular}

Source: Author's own research

One interesting aspect is an insight into the first association of Novi Sad from the point of those who lived in Novi Sad before studies and those who did not, and if so, whether they came from a rural or from an urban area. Although the first association to all segments remains "architecture and ambience", to those who lived in rural area before moving to Novi Sad, 4th association is "culture, tamburaši-musicians and Djordje Balasevic" (10.5\%), whereas to those who lived in Novi Sad before studies, 4th association is "multiculture" $(10.3 \%)$, as represented in Table 3 . 
Table 3: Connection between the place of origin and the first association of Novi Sad

\begin{tabular}{|c|c|c|c|c|}
\hline \multirow[b]{2}{*}{$\begin{array}{l}\text { First association of } \\
\text { Novi Sad }\end{array}$} & \multicolumn{3}{|c|}{ Place of living before studies } & \multirow[b]{2}{*}{ Total } \\
\hline & Novi Sad & $\begin{array}{l}\text { Outside } \\
\text { NS, rural } \\
\text { area } \\
\end{array}$ & $\begin{array}{l}\text { Outside NS, } \\
\text { urban area }\end{array}$ & \\
\hline Architecture and ambience & $35.9 \%$ & $36.8 \%$ & $36.0 \%$ & $36.3 \%$ \\
\hline Byciclers & $7.7 \%$ & $0.0 \%$ & $4.0 \%$ & $3.9 \%$ \\
\hline Danube, quay, Strand & $17.9 \%$ & $21.1 \%$ & $20.0 \%$ & $19.6 \%$ \\
\hline Exit and other festivals & $12.8 \%$ & $21.1 \%$ & $24.0 \%$ & $18.6 \%$ \\
\hline Food and drink & $5.1 \%$ & $5.3 \%$ & $4.0 \%$ & $4.9 \%$ \\
\hline IT industry & $2.6 \%$ & $0.0 \%$ & $0.0 \%$ & $1.0 \%$ \\
\hline Culture & $2.6 \%$ & $10.5 \%$ & $0.0 \%$ & $4.9 \%$ \\
\hline People & $5.1 \%$ & $0.0 \%$ & $4.0 \%$ & $2.9 \%$ \\
\hline Multiculture & $10.3 \%$ & $5.3 \%$ & $8.0 \%$ & $7.8 \%$ \\
\hline Total & $100.0 \%$ & $100.0 \%$ & $100.0 \%$ & $100.0 \%$ \\
\hline
\end{tabular}

Source: Author's own research

Table 4 represents answers to questions related to whether respondents consider events as a significant characteristic of Novi Sad. Here, too we can see compliance with the above mentioned research in which respondents were giving grades from 1 to 5 to certain characteristics, and the highest rated ones were those related to "diversified and quality festivals and cultural events" (Grad Novi Sad, 2018).

Table 4: Importance of events for Novi Sad

\begin{tabular}{|c|c|c|c|c|c|c|c|}
\hline \multicolumn{4}{|c|}{ Question } & Yes & No & I don't kr & Total \\
\hline \multicolumn{4}{|c|}{$\begin{array}{l}\text { Do you think that manifestations are an important characteristic of } \\
\text { Novi Sad? }\end{array}$} & $90.2 \%$ & $3.9 \%$ & $5.9 \%$ & $\begin{array}{l}100 \\
\%\end{array}$ \\
\hline \multicolumn{4}{|c|}{ Do you think that Novi Sad is recognisable by its events? } & $80.4 \%$ & $9.8 \%$ & $9.8 \%$ & $\begin{array}{l}100 \\
\%\end{array}$ \\
\hline \multicolumn{4}{|c|}{$\begin{array}{l}\text { Do you know that Novi Sad has got a title of European Capital of } \\
\text { Culture? }\end{array}$} & $89.2 \%$ & $2.9 \%$ & $7.8 \%$ & $\begin{array}{l}100 \\
\%\end{array}$ \\
\hline \multirow{2}{*}{$\begin{array}{l}\text { Do you think that Novi Sad has a } \\
\text { sufficient number of events? }\end{array}$} & Yes & No & \multicolumn{2}{|c|}{$\begin{array}{c}\text { There should be } \\
\text { even more }\end{array}$} & \multicolumn{2}{|c|}{$\begin{array}{c}\text { There should } \\
\text { be less }\end{array}$} & $\begin{array}{l}\text { I am not } \\
\text { sure }\end{array}$ \\
\hline & $54.9 \%$ & $1.0 \%$ & & $32.4 \%$ & & $1.0 \%$ & $0.8 \%$ \\
\hline
\end{tabular}

Source: Author's own research

Question no. 5 is created in such a way to assess knowledge dimension of a brand, i.e. whether respondents can remember brands, or festivals, therefore they were asked to name all festivals they can remember. The strongest awareness was expressed for the Exit festival, which was mentioned by $86 \%$ of respondents. The following festivals are "Zmajeve dečje igre" $(33 \%)$ and "Tamburica fest" $(32 \%)$. The total number of festivals that respondents thought of in this question was 17 (Table 5). 
Jojić Novaković, Đ., Mandarić, M. - Do events contribute to the brand of Novi Sad? A millennials`perspectiveHotel and Tourism Management, 2019, Vol. 7, No. 1: 47-59.

Table 5: Awareness of brands of festivals - respondents' memory

\begin{tabular}{|r|l|c|}
\hline No. & \multicolumn{1}{|c|}{ Manifestation } & $\begin{array}{c}\text { Frequency } \\
(\%)\end{array}$ \\
\hline 1 & Exit & $86 \%$ \\
\hline 2 & Zmajeve dečje igre & $33 \%$ \\
\hline 3 & Tamburica fest & $32 \%$ \\
\hline 4 & $\begin{array}{l}\text { International Agricultural } \\
\text { Fair }\end{array}$ & $25 \%$ \\
\hline 5 & Ledena šuma & $23 \%$ \\
\hline 6 & Street musicians festival & $20 \%$ \\
\hline 7 & Serbia Fashion Week & $20 \%$ \\
\hline 8 & Fruška gora trail & $19 \%$ \\
\hline
\end{tabular}

\begin{tabular}{|r|l|c|}
\hline No. & \multicolumn{1}{|c|}{ Manifestation } & $\begin{array}{c}\text { Frequency } \\
(\%)\end{array}$ \\
\hline 9 & Museum night & $15 \%$ \\
\hline 10 & Interfest & $12 \%$ \\
\hline 11 & $\begin{array}{l}\text { Novosadski festival zanatskog } \\
\text { piva }\end{array}$ & $11 \%$ \\
\hline 12 & Sterijino pozorje & $11 \%$ \\
\hline 13 & Day of young portugieser & $8 \%$ \\
\hline 14 & Koncert godine & $8 \%$ \\
\hline 15 & Fair of tourism & $8 \%$ \\
\hline 16 & $\begin{array}{l}\text { LORIST }- \text { Hunting and Fishing } \\
\text { Fair, Sports Expo }\end{array}$ & $4 \%$ \\
\hline 17 & Winter fest & $2 \%$ \\
\hline
\end{tabular}

Source: Author's own research

In question no. 6 (Table 6) respondents named which of the given events they have visited. Events were listed as in the official calendar of Tourism Organisation of Novi Sad (TO Novog Sada, 2018). What we can see in this case is that respondents' events visits do not correspond to those they have awareness of, i.e. whose brands are known to them. This refers mostly to "Exit festival" and we can explain these with the fact that the ticket price exceeds the purchasing power of respondents. The most visited events are "Ledena šuma" and "New Year's Eve“. The least visited are events related to cultural manifestations with more serious content such as avant-garde theatre and classical music ("Infant" $0 \%$, "Piano City" 0\%, "Nomus" 3\%, "Boat Theatre" 5\%, "Jazz festival Novi Sad "6\%).

Table 6: Events visited by respondents

\begin{tabular}{|r|l|c|}
\hline No. & \multicolumn{1}{|c|}{ Manifestation } & $\begin{array}{c}\text { Frequency } \\
(\mathbf{\%})\end{array}$ \\
\hline 1 & Ledena šuma & $71 \%$ \\
\hline 2 & Doček nove godine & $63 \%$ \\
\hline 3 & Exit & $52 \%$ \\
\hline 4 & Museum night & $37 \%$ \\
\hline 5 & Festival uličnih svirača & $37 \%$ \\
\hline 6 & Fruška gora trail & $36 \%$ \\
\hline 7 & International Agricultural & $36 \%$ \\
\hline 8 & Zair & $36 \%$ \\
\hline 9 & Serbia Fashion Week & $29 \%$ \\
\hline 10 & Novosadski Oktoberfest & $29 \%$ \\
\hline 11 & Tamburica fest & $26 \%$ \\
\hline 12 & Interfest & $24 \%$ \\
\hline 13 & Koncert godine & $20 \%$ \\
\hline 14 & $\begin{array}{l}\text { LORIST }- \text { Hunting and } \\
\text { Fishing Fair, Sports Expo }\end{array}$ \\
\hline
\end{tabular}

\begin{tabular}{|r|l|c|}
\hline No. & \multicolumn{1}{|c|}{ Manifestation } & $\begin{array}{c}\text { Frequency } \\
(\%)\end{array}$ \\
\hline 15 & Novosadski noćni market & $16 \%$ \\
\hline 16 & Researchers' night & $15 \%$ \\
\hline 17 & $\begin{array}{l}\text { Novosadski festival zanatskog } \\
\text { piva }\end{array}$ & $14 \%$ \\
\hline 18 & Ukusi Vojvodine & $14 \%$ \\
\hline 19 & Sterijino pozorje & $12 \%$ \\
\hline 20 & Cars Fair & $12 \%$ \\
\hline 21 & Novi Sad half marathon & $10 \%$ \\
\hline 22 & Day of young portugieser & $10 \%$ \\
\hline 23 & Jazz festival Novi Sad & $6 \%$ \\
\hline 24 & Boat theatre & $5 \%$ \\
\hline 25 & Nomus & $3 \%$ \\
\hline 26 & Infant & $0 \%$ \\
\hline 27 & Piano City & $0 \%$ \\
\hline
\end{tabular}

Source: Author's own research

In the next, $7^{\text {th }}$ question, respondents were asked to rank 10 most important events who contributed to obtaining the title of European Capital of Culture 2021 for Novi Sad. Ranking was done in such way that the $1^{\text {st }}$ event obtained 10 points, $2^{\text {nd }}$ event obtained 9 points and so on. Then means were calculated for each event, and repsresented in table 7. The "Exit" is 
still considered to be the most important event (average grade 8.6), but quite important are also "Ledena šuma" (6.8), "International Agricultural Fair" (6.7) and "Nomus" (6.4).

Table 7: Importance of events for obtaining the title of 2021European Capital of Culture

\begin{tabular}{|r|l|c|}
\hline No. & Manifestation & Average \\
\hline 1 & Exit & 8.6 \\
\hline 2 & Ledena šuma & 6.8 \\
\hline 3 & $\begin{array}{l}\text { International } \\
\text { Agricultural } \\
\text { Fair }\end{array}$ & 6.7 \\
\hline 4 & Nomus & 6.4 \\
\hline 5 & $\begin{array}{l}\text { Street } \\
\text { musicians } \\
\text { festival }\end{array}$ & 5.8 \\
\hline 6 & $\begin{array}{l}\text { Fruška gora } \\
\text { trail }\end{array}$ & 5.7 \\
\hline 7 & $\begin{array}{l}\text { Researchers' } \\
\text { night }\end{array}$ & 5.6 \\
\hline 8 & $\begin{array}{l}\text { Novosadski } \\
\text { noćni market }\end{array}$ & 5.5 \\
\hline 9 & $\begin{array}{l}\text { Doček nove } \\
\text { godine }\end{array}$ & 5.5 \\
\hline
\end{tabular}

\begin{tabular}{|c|l|c|}
\hline No. & Manifestation & Average \\
\hline 10 & $\begin{array}{l}\text { Day of young } \\
\text { portugieser }\end{array}$ & 5.5 \\
\hline 11 & $\begin{array}{l}\text { Serbia Fashion } \\
\text { Week }\end{array}$ & 5.5 \\
\hline 12 & Piano City & 5.4 \\
\hline 13 & Koncert godine & 5.4 \\
\hline 14 & Museum night & 5.3 \\
\hline 15 & $\begin{array}{l}\text { Novosadski } \\
\text { Oktoberfest }\end{array}$ & 5.3 \\
\hline 16 & $\begin{array}{l}\text { Novi Sad half } \\
\text { marathon }\end{array}$ & 5.3 \\
\hline 17 & Tamburica fest & 5.3 \\
\hline 18 & $\begin{array}{l}\text { Sterijino } \\
\text { pozorje }\end{array}$ & 5.2 \\
\hline
\end{tabular}

\begin{tabular}{|c|l|c|}
\hline No. & \multicolumn{1}{|c|}{ Manifestation } & Average \\
\hline 19 & Infant & 5.1 \\
\hline 20 & $\begin{array}{l}\text { LORIST - Hunting } \\
\text { and Fishing Fair, } \\
\text { Sports Expo }\end{array}$ & 5.0 \\
\hline 21 & Cars fair & 4.6 \\
\hline 22 & Interfest & 4.5 \\
\hline 23 & $\begin{array}{l}\text { Jazz festival Novi } \\
\text { Sad }\end{array}$ & 4.3 \\
\hline 24 & Zmajeve dečje igre & 4.2 \\
\hline 25 & $\begin{array}{l}\text { Novosadski } \\
\text { festival zanatskog } \\
\text { piva }\end{array}$ & 4.1 \\
\hline 26 & Ukusi Vojvodine & 4.0 \\
\hline 27 & Boat theatre & 3.4 \\
\hline
\end{tabular}

Source: Author's own research

Respondents were giving answers to the next question related to which events contribute most to the image of Novi Sad. Table 8 contains events that were the most frequently mentioned. The "Exit" dominates in this segment, too, as it was mentioned 83 times but this time, unlike for the events important for obtaining title of European Culture capital 2021, respondents think that also economic and cultural manifestations are important for the city's image: "International Agricultural Fair" (17 mentions), "Tamburica fest" (14 mentions), "Zmajeve dečje igre" (11 mentions), "Ledena šuma" and "Sterijino pozorje" (10 mentions).

Table 8: Importance of events from the point of contribution to the city's image

\begin{tabular}{|r|l|r|}
\hline No. & \multicolumn{1}{|c|}{ Manifestation } & \multicolumn{1}{c|}{$\begin{array}{c}\text { Number of } \\
\text { mentions }\end{array}$} \\
\hline 1 & Exit & 83 \\
\hline 2 & International Agricultural Fair & 17 \\
\hline 3 & Tamburica fest & 14 \\
\hline 4 & Zmajeve dečje igre & 11 \\
\hline 5 & Ledena šuma & 10 \\
\hline 6 & Sterijino pozorje & 10 \\
\hline 7 & Fruška gora trail & 8 \\
\hline 8 & Serbia Fashion Week & 7 \\
\hline 9 & Museum night & 7 \\
\hline 10 & Novosadski Oktoberfest & 7 \\
\hline 11 & Jazz festival Novi Sad & 7 \\
\hline 12 & Doček nove godine & 7 \\
\hline 13 & Nomus & 6 \\
\hline 14 & Street musicians festivalvirača & 6 \\
\hline
\end{tabular}

\begin{tabular}{|r|l|r|}
\hline No. & \multicolumn{1}{|c|}{ Manifestation } & \multicolumn{1}{|c|}{$\begin{array}{c}\text { Number of } \\
\text { mentions }\end{array}$} \\
\hline 15 & Cars fair & 5 \\
\hline 16 & Interfest & 4 \\
\hline 17 & $\begin{array}{l}\text { LORIST - Hunting and } \\
\text { Fishing Fair, Sports Expo }\end{array}$ & 4 \\
\hline 18 & Novi Sad half marathon & 3 \\
\hline 19 & Boat theatre & 3 \\
\hline 20 & Infant & 3 \\
\hline 21 & Piano City & 3 \\
\hline 22 & Koncert godine & 3 \\
\hline 23 & Researchers' night & 2 \\
\hline 24 & $\begin{array}{l}\text { Novosadski festival } \\
\text { zanatskog piva }\end{array}$ & 1 \\
\hline 25 & Ukusi Vojvodine & 1 \\
\hline 26 & Day of young portugieser & 1 \\
\hline 27 & Novosadski noćni market & 1 \\
\hline
\end{tabular}

Source: Author's own research 
Jojić Novaković, Đ., Mandarić, M. - Do events contribute to the brand of Novi Sad? A millennials`perspectiveHotel and Tourism Management, 2019, Vol. 7, No. 1: 47-59.

The largest number of respondents believe that events should remain one of characteristics of Novi Sad $(38.2 \%)$, followed by culture, people, atmosphere and architecture $(15.7 \%, 14.5 \%$, $13.7 \%$ i $11.8 \%$, respectively) (Table 9).

Table 9: Future desirable marks of Novi Sad

\begin{tabular}{|l|l|c|c|}
\hline No. & \multicolumn{1}{|c|}{ Mark } & N. of respondents & \% \\
\hline 1 & Manifestations & 39 & 38.2 \\
\hline 2 & Culture & 15 & 15.7 \\
\hline 3 & People & 15 & 14.5 \\
\hline 4 & Atmosphere & 14 & 13.7 \\
\hline 5 & Architecture & 12 & 11.8 \\
\hline 6 & Gastronomy & 6 & 5.9 \\
\hline & & $\mathbf{1 0 2}$ & $\mathbf{1 0 0 . 0}$ \\
\hline
\end{tabular}

Source: Author's own research

The next question was also open-ended and it referred to what type of manifestations can improve the image of Novi Sad. All answers can be grouped into 8 categories presented in table 10 . The majority has chosen concerts $(24.5 \%)$ as well as other types of cultural manifestations $(19.6 \%)$, followed by events that promote local gastronomy and wines $(14.7 \%)$.

Table 10: Manifestations that can improve the image of Novi Sad

\begin{tabular}{|c|c|c|c|c|c|c|c|c|c|}
\hline No. & 1 & 2 & 3 & 4 & 5 & 6 & 7 & 8 & Total \\
\hline $\begin{array}{c}\text { Type of } \\
\text { manifestation }\end{array}$ & Concerts & Culture & Gastronomy & Dances & $\begin{array}{c}\text { Youth } \\
\text { related }\end{array}$ & Sports & $\begin{array}{c}\text { Avant- } \\
\text { garde, } \\
\text { modern }\end{array}$ & $\begin{array}{c}\text { Open } \\
\text { space }\end{array}$ & $\begin{array}{c}\text { No. of } \\
\text { respondents }\end{array}$ \\
\hline$\%$ & 20 & 15 & 9 & 9 & 9 & 8 & 7 & $\mathbf{1 0 2}$ \\
\hline$\%$ & 24.5 & 19.6 & 14.7 & 8.8 & 8.8 & 8.8 & 7.8 & 6.9 & $\mathbf{1 0 0}$ \\
\hline
\end{tabular}

Source: Author's own research

Lastly, respondents were asked about direct and indirect effects that Novi Sad has from manifestations. All answers were grouped into 6 categories and are presented in table 11 . The majority recognises the importance of events as a source of revenues $(66 \%)$ and as a tool for improving the image and recognisiblity of Novi Sad (55\%). However, $16 \%$ of respondents think that events have some negative effects, too, in terms of pollution and destroying the nature and objects of the city.

Table 11: Events' effect on Novi Sad

\begin{tabular}{|l|l|c|c|}
\hline No. & \multicolumn{1}{|c|}{ Effect } & $\begin{array}{c}\text { No. of } \\
\text { respondents }\end{array}$ & $\%$ \\
\hline 1 & Revenues & 67 & $66 \%$ \\
\hline 2 & $\begin{array}{l}\text { Image and } \\
\text { recognisablity }\end{array}$ & 56 & $55 \%$ \\
\hline 3 & $\begin{array}{l}\text { More visitors }- \\
\text { tourism }\end{array}$ & 33 & $32 \%$ \\
\hline
\end{tabular}

\begin{tabular}{|l|l|c|c|}
\hline No. & \multicolumn{1}{|c|}{ Effect } & $\begin{array}{c}\text { No. of } \\
\text { respondents }\end{array}$ & $\%$ \\
\hline 4 & $\begin{array}{l}\text { Pollution, destroying } \\
\text { nature and objects }\end{array}$ & 16 & $16 \%$ \\
\hline 5 & $\begin{array}{l}\text { Learning about the } \\
\text { city and local culture }\end{array}$ & 10 & $10 \%$ \\
\hline 6 & $\begin{array}{l}\text { Influence on } \\
\text { economy and citizens }\end{array}$ & 9 & $9 \%$ \\
\hline
\end{tabular}

Source: Author's own research

These answers show that young people do have certain consciousness about environment protection and factors that have an influence on it.

\subsection{Limitations and directions for future research}

The limitations of the research should be taken into account when making conclusions and formulating recommendations for some future researches. 
Firstly, the biased opinion of respondents can be expressed in two ways. One way refers to the fact that this research examines only the attitude of inhabitants of Novi Sad who, with or without intention to be biased, may have been providing subjective answers to questions in the questionnaire. Inhabitants of other cities could be included in the sample for some future research, which would enable more in-depth view of the importance of festivals for the branding of Novi Sad.

Secondly, a limit of the research is related to the fact that the sample consists only of students who live in Novi Sad, which could have influenced on results in favour of some events. Therefore, the research could be expanded to those inhabitants who do not attend the university.

Thirdly, it is desirable to develop techniques of measuring the effects of manifestations on Novi Sad, which will be based on more objective criteria, rather than on subjective opinion. This would ensure a more realistic base for future investment in culture and for assessment of important components of brand strategy.

\section{Conclusion}

This research has proven that events definitely are considered as one of the marks of Novi Sad in the eyes of the most growing population - millennials. Although there are slight differences, we can say that a brand of Novi Sad is consistently positioned so that both residents and tourists, and both millennials and other generations, have the same or quite similar perception of what makes city's identity and its value as a brand.

It is also notable that although millennials do not attend certain events, such as "Nomus", "Piano City" or "Sterijino pozorje" they do understand their importance.

The "Exit festival" is convincingly dominating in all aspects, which makes it one of the most important marks not only of Novi Sad but of Serbia in general.

The benefits of Novi Sad branding in the stated context are numerous:

- Strengthening the identity of Novi Sad as of a "city of festivals";

- Channelling direction of the development of city's tourism in accordance with strategically defined tourist products, one of them being events and manifestations;

- Strengthening positive image that millennials have got about the city; this is the generation that will soon dominate city's population and that will be a key player in economic and other activities in the city;

- A positive image of popular international festivals, primarily the "Exit festival" is being transferred to the city of Novi Sad;

- Indirectly, all above mentioned is making the destination more popular, attracts more tourists and generates more revenues both for the Budget of the city and for businesses and citizens.

Therefore as a last point of the conclusion, it can be stated that the vision of the city of Novi Sad is properly defined, taking into account all answers obtained from this research. The official vision of the city of Novi Sad states as follows:

"Novi Sad in 2025 is a modern Europan city, culture capital, youth capital, a capital of European values and of European lifestyle, which attracts people to visit it and to live in it with its urban contents, tradition and multicultural environment.

Novi Sad is a city which welcomes all people with an open heart and open arms, a city that knows how to tell its story and that is proud of its tradition and its values. By continuously 
investing in new knowledge, digital technologies and technological growth and development, Novi Sad enables stable development in the best interest of its citizens.

Novi Sad leans on tourism to a great extent, not only as its tool for development but mostly as an efficient medium for global presentation of its identity and achievements. By innovatively converting and arrangeing city's core area, by arranging Petrovaradin and its part Podgradje, by introducing content and developing areas on the banks of Danube, Novi Sad creates unique zones of experience, it seizes people who come to visit it with its charm and it gives them a role of co-habitant who can have fun and experience cultural, historical and natural values of Novi Sad and its specific lifestyle in the proper manner" (Grad Novi $\underline{\text { Sad, 2018). }}$

\section{References}

1. Anastassova, L., \& Luizov, A. (2016). Marketing urban destinations through festivals. Revista de turism - studii si cercetari in turism, 21, 43-49

2. Arnegger, J., \& Herz, M. (2016). Economic and destination image impacts of megaevents in emerging tourist destinations. Journal of Destination Marketing \& Management, 5(2), 76-85. https://doi.org/10.1016/j.jdmm.2015.11.007

3. Ashworth, G., \& Kavaratzis, M. (2009). Beyond the logo: Brand management for cities. Journal of Brand Management, 16, 520-531. https://doi.org/10.1057/palgrave.bm.2550133

4. European Commission. (2014). European Capitals of Culture 2020 to 2033 - A guide for cities preparing to bid. Brusselles: European Commission.

5. European Commission. (2018). European Capitals of Culture. Retrieved June 8, 2018 from: https://ec.europa.eu/programmes/creative-europe/actions/capitals-culture en

6. Folorunso Adeyinka-Ojo, S., \& Khoo-Lattimore, C. (2013). Slow food events as a high yield strategy for rural tourism destinations. Worldwide Hospitality and Tourism Themes, 5(4), 353-364. https://doi.org/10.1108/WHATT-03-2013-0012

7. Fromm, J. (2011). Do you have a millenial marketing strategy? Franchising World, 43(9), 56-57

8. Getz, D. (2016, August 9). The Sustainability Of Eventful Cities. Retrieved June 9, 2018 from: https://donaldgetzprofessor.wordpress.com/2016/08/09/new-download-thesustainability-of-eventful-cities/

9. Grad Novi Sad. (2018). Program razvoja turizma grada Novog Sada za period 20182022. godine [Programme of tourism development of the city of Novi Sad for the period 2018-2022]. Novi Sad: Grad Novi Sad.

10. Hankinson, G. (2009). Managing destination brands: establishing a theoretical foundation. Journal of Marketing Management, 25(1-2), 97-115. https://doi.org/10.1362/026725709X410052

11. Henderson, S. (2011). The development of competitive advantage through sustainable event management. Worldwide Hospitality and Tourism Themes, 3(3), 245-257. https://doi.org/10.1108/17554211111142202

12. Kavaratzis, M. (2004). From city marketing to city branding: Towards a theoretical framework for developing city brands. Place Branding, 1(1), 58-73. https://doi.org/10.1057/palgrave.pb.5990005

13. Kotler, P., \& Gertner, D. (2002). Country as a brand, product, and beyond: A place marketing and brand management perspective. Brand Management, 9(4-5), 249-261. https://doi.org/10.1057/palgrave.bm.2540076

14. Lee, I., \& Arcodia, C. (2011). The role of regional food festivals for destination branding. International Journal of Tourism Research, 13(4), 355-367. https://doi.org/10.1002/jtr.852 
15. Mandarić, M. (2016). Strategijski brend menadžment [Strategic brand management]. Vrnjačka banja: Fakultet za hotelijerstvo i turizam u Vrnjačkoj Banji.

16. Mandarić, M., \& Milićević, S. (2016). Role And Significance Of Tourism Destinations Branding. 3rd International Conference: "Higher education in function of development of tourism in Serbia and Western Balkans", Visoka škola strukovnih studija, Užice, 3746.

17. Mandarić, M., Milićević, S., \& Sekulić, D. (2017). Traditional values in the function of promotion of Šumadija and Pomoravlje as rural tourism destinations. Economics of Agriculture, 64(2), 787-803. https://doi.org/10.5937/ekopolj1702787m

18. Mason, M., \& Paggiaro, A. (2012). Investigating the role of festivalscape in culinary tourism: The case of food and wine events. Tourism Management, 33(6), 1329-1336. https://doi.org/10.1016/j.tourman.2011.12.016

19. Morgan, N., Pritchard, A., \& Pride, R. (2015). Destination brands - Managing place reputaion. Beograd: Clio

20. Novi Sad 2021. (2018). What is European Capital of Culture? Retrieved June 8, 2018 from: http://novisad2021.rs/en/what-is-european-capital-of-culture/?jez=lat

21. Nunkoo, R., \& Gursoy, D. (2012). Residents' support for tourism. Annals of Tourism Research, 39(1), 243-268. https://doi.org/10.1016/j.annals.2011.05.006

22. Ooi, C.-S., \& Strandgaard Pedersen, J. (2010). City branding and film festivals: Reevaluating stakeholder's relations. Place Branding and Public Diplomacy, 6(4), 316332. https://doi.org/10.1057/pb.2010.30

23. Paddison, B., \& Biggins, R. (2017). Advocating community integrated destination marketing planning in heritage destinations: the case of York. Journal of Marketing Management, 33(9-10), 835-857. https://doi.org/10.1080/0267257X.2017.1329226

24. Richards, G., \& Wilson, J. (2004). The impact of cultural events on city image: Rotterdam, Cultural capital of Europe 2001. Urban Studies, 41(10), 1931-1951. https://doi.org/10.1080/0042098042000256323

25. Riza, M. (2015). Culture and city branding: Mega-events and iconic buildings as fragile means to brand the city. Open Journal of Social Sciences, 3(7), 269-274. https://doi.org/10.4236/jss.2015.37039

26. Ryan, C., \& Montgomery, D. (1994). The attitudes of bakewell residents to tourism and issues in community responsive tourism. Tourism Management, 15(5), 358-369. https://doi.org/10.1016/0261-5177(94)90090-6

27. Starčević, S., \& Konjikušić, S. (2018). Why millennials as digital travelers transformed marketing strategy in tourism industry. Conferene Proceedings - 3rd Tourism International Scientific Conference Vrnjačka banja. Vrnjačka banja: Fakultet za hotelijerstvo i turizam u Vrnjačkoj banji

28. TO Novog Sada. (2018, May 15). Događaji [Events]. Retreived May 15, 2018 from: http://novisad.travel/dogadjaji/

29. Veljković, S. (2010). Brend menadžment u savremenim tržišnim uslovima [Brand management in contemporary market conditions]. Beograd: Centar za izdavačku delatnost Ekonomskog fakulteta u Beogradu

30. Vlada Republike Srbije. (2016). Strategija razvoja turizma Republike Srbije 2016-2025 [Strategy of tourism development of the Republic of Serbia 2016-2025]. Beograd: Vlada Republike Srbije

31. Yuan, J., \& Jang, S. (2008). The effects of quality and satisfaction on awareness and behavioral intentions: Exploring the role of a wine festival. Journal of Travel Research, 46(3), 279-288. https://doi.org/10.1177/0047287507308322

32. Yuan, L., \& Chong, C. (2006). The effects of festivals and special events on city image design. Architecture Journal, 1(2), 255-259.https://doi.org/10.1007/s11709-007-0032-0

Received: 27 November 2018; Sent for revision: 21 April 2019; Accepted: 13 May 2019 